\title{
The $\mathrm{ACTH}_{4-9}$ analog ORG 2766 'normalizes' the changes in motor activities of rats elicited by housing and test conditions
}

\author{
Gerrit Wolterink and Jan M. Van Ree \\ Rudolf Magnus Institute for Pharmacology, Medical Faculty, University of Utrecht, Utrecht (The Netherlands)
}

(Accepted 10 February 1987)

Key words: ORG 2766; $\mathrm{ACTH}_{4-10}$; Motor activity; Short-term isolation; Opioid; Naltrexone

\begin{abstract}
Motor activities of rats were decreased by short-term ( 7 days) social isolation as well as by intense light test conditions. The $\mathrm{ACTH}_{4-9}$ analog ORG 2766, s.c. administered $50 \mathrm{~min}$ before testing, dose-dependently decreased the high motor activities of grouphoused rats tested under low light conditions and increased the low motor activities of short-term isolated rats tested under intense light conditions $\left(\mathrm{ED}_{50}: 0.01-0.03 \mu \mathrm{g} / \mathrm{kg}\right.$ ). Structure-activity studies suggest that the essential structure for these effects may be located in the C-terminal tripeptide Phe-D-Lys-Phe. Treatment with $\mathrm{ACTH}_{4-10}(100 \mu \mathrm{g} / \mathrm{kg})$ tended to enhance some of the effects of the environmental conditions. Pretreatment of rats with the opioid antagonist naltrexone $(450 \mu \mathrm{g} / \mathrm{kg}, \mathrm{s} . \mathrm{c}$.) completely blocked the 'normalizing' effects of ORG 2766, implicating endogenous opioids in this action of ORG 2766. Since social behaviors of rats are similarly affected by ORG 2766 as motor activities, it is suggested that this peptide affects the integration of sensoric stimuli rather than the specific motor output systems of these behaviors.
\end{abstract}

\section{INTRODUCTION}

Neuropeptides derived from adrenocorticotropic hormone $(\mathrm{ACTH})$ are thought to be involved in the regulation of emotional processes. Several human studies have shown that $\mathrm{ACTH}_{4-10}$ and the $\mathrm{ACTH}_{4-9}$ analog ORG 2766 affect behaviors in which emotional components are involved ${ }^{1,9,24}$. The behavioral influence of these peptides in animals has been described as a facilitated motivation and enhanced concentration and attention ${ }^{5}$. Also in humans these peptides may have an influence on motivation and attention, especially in subjects with slight disturbances in these functions ${ }^{24}$. In addition, ORG 2766 appears to elevate mood and to increase sociability in some geriatric and mentally retarded patients $\mathbf{s}^{22,24}$.

In rats, these peptides delay extinction of active avoidance behavior, ORG 2766 being approximately 1000 times more potent than $\mathrm{ACTH}_{4-10}$ (refs. 4, 6). Retention of passive avoidance behavior is facili- tated by $\mathrm{ACTH}_{4-10}$ (refs. 6-8). Low doses of ORG 2766 mimic this effect of $\mathrm{ACTH}_{4-10}$, but high doses of ORG 2766 induce the opposite effect, i.e. attenuate the retention of passive avoidance behavior ${ }^{6-8}$. Structure-activity studies revealed that the facilitating effect of ORG 2766 is located in the $\mathrm{NH}_{2}$-terminal tetrapeptide, while the attenuating effect of high doses of ORG 2766 is present in its COOH-terminal tripeptide Phe-D-Lys-Phe. File ${ }^{13}$ and Niesink and Van $\operatorname{Re}^{20,21}$ have reported effects of $\mathrm{ACTH}_{4-10}$ and ORG 2766 on social behaviors of rats. The intensity of social behavior can be influenced by changes in housing conditions before testing and in environmental conditions during testing. Thus, the duration and frequency of social interactions are increased by short-term ( 7 days) isolation and decreased by exposing rats to an unfamiliar test-cage under a high level of illumination. Both the increase and decrease of social interactions can be attenuated by treatment with ORG 2766. Similar treatment with $\mathrm{ACTH}_{4-10}$ is not

Correspondence: G. Wolterink, Rudolf Magnus Institute for Pharmacology, Medical Faculty, University of Utrecht, Vondellaan 6, 3521 GD Utrecht, The Netherlands. 
effective or has an opposite effect as compared to ORG 2766. The effects of ORG 2766 may be mediated by an opioid receptor system since pretreatment with naltrexone completely antagonized the influence of the peptide.

The aim of the present study was to assess whether the mentioned effects of $\mathrm{ACTH}_{4-10}$ and ORG 2766 are specific for social behavior or can be generalized to other behaviors that are susceptible to changes in housing conditions before and in environmental conditions during testing. Therefore we investigated the influence of $\mathrm{ACTH}_{4-10}$, ORG 2766 and related peptides on changes in motor activity induced by identical housing and environmental conditions as used by Niesink and Van Ree ${ }^{20,21}$ in their studies on social behavior of rats.

\section{MATERIALS AND METHODS}

Male Wistar rats bred from our own live stock weighing between 180 and $220 \mathrm{~g}$ at the time of testing were used. The rats were housed in wire cages in groups of approximately 20 animals. Two weeks prior to experimentation the rats were housed in a dimly lighted animal room (20-40 Lux, lights on $07.00 \mathrm{~h}$, off $19.00 \mathrm{~h}$ ), in plastic home cages measuring $40 \times 26 \times 20 \mathrm{~cm}(1 \times \mathrm{w} \times \mathrm{h})$ in groups of 5 animals per cage. Part of the animals were single-housed in cages measuring $22 \times 13 \times 20 \mathrm{~cm}(1 \times \mathrm{w} \times \mathrm{h}) 7$ days before testing. The animal room was temperature controlled $\left(25^{\circ} \mathrm{C}\right)$ and standard food and tap water were available ad libitum. Animals were used only once.

\section{Test procedure}

Testing was performed in a sound-attenuated room. Background noise was produced by a fan. On the day of experimentation the rats were brought to a dark room adjacent to the test room at least $1 \mathrm{~h}$ before testing. The rats were tested in a small open field either under low light conditions (red light, 0.4-1 Lux) or under intense light conditions (white light, 572 Lux). The animals received a subcutaneous injection with saline or peptide $50 \mathrm{~min}$ before testing. Behavioral activity of the rats was assessed in an open field as described before ${ }^{28}$. The open field consisted of a round Plexiglas tube (diameter $19.5 \mathrm{~cm}, \mathrm{~h}$ $30 \mathrm{~cm}$ ) placed on a plastic board which was divided into 4 equal sections. During a 3 -min observation period motor activity (number of sections explored), rearing (number of times the rat stood on its hind legs) and total sniffing time were determined.

\section{Drugs}

The following peptides were used: $\mathrm{ACTH}_{4-10}$ (Met-

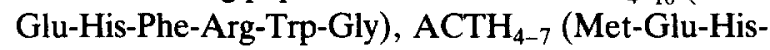
$\mathrm{Phe}),\left[\mathrm{Met} / \mathrm{O}_{2} / \mathrm{ACTH}_{4-7} \quad\left(\mathrm{Met} / \mathrm{O}_{2} /\right.\right.$-Glu-His-Phe $)$, $\mathrm{ACTH}_{7-10}$ (Phe-Arg-Trp-Gly), [D-Phe ${ }^{7} \mathrm{ACTH}_{4-10}$ (Met-Glu-His-D-Phe-Arg-Trp-Gly), ORG 2766 (Met/ $\mathrm{O}_{2}$ /-Glu-His-Phe-D-Lys-Phe), WB1438 (Met/O $/$ /-AlaAla-Phe-D-Lys-Phe-Gly-D-Lys-Pro-Val-Gly-Lys-Lys$\mathrm{NH}_{2}$ ), PDLP (Phe-D-Lys-Phe) and $\gamma$-MSH (Tyr-ValMet-Gly-His-Phe-Arg-Trp-Asp-Arg-Phe-Gly). The peptides were supplied by Organon International B.V., Oss, The Netherlands. Naltrexone was obtained from Endo Laboratories. All substances were dissolved in saline in plastic containers on the day of testing. Injections were given through plastic syringes.

\section{Statistics}

Statistical analysis of the data was performed using parametric tests (ANOVA, Student/Newman-Keuls tests).

\section{RESULTS}

The effects of housing conditions before testing and level of illumination during testing on the motor, rearing and sniffing activities of the rats are shown in Fig. 1. Rats that were tested under intense light or that were single-housed for 7 days showed a significant reduction in motor and rearing activities as compared to rats that were tested under low light intensity or were group-housed respectively. The effects of the housing condition before and level of illumination during testing on the motor and rearing activities of rats were additive. Since, in general, motor and rearing activities were similarly affected by the changes in housing and test conditions, only the data on motor activity are further presented. A significant effect of housing conditions before and the level of illumination during testing on total sniffing time was never observed in any of the experiments.

A subcutaneous injection of ORG $276650 \mathrm{~min}$ before testing dose-dependently reduced the motor activity of group-housed rats tested under low light in- 

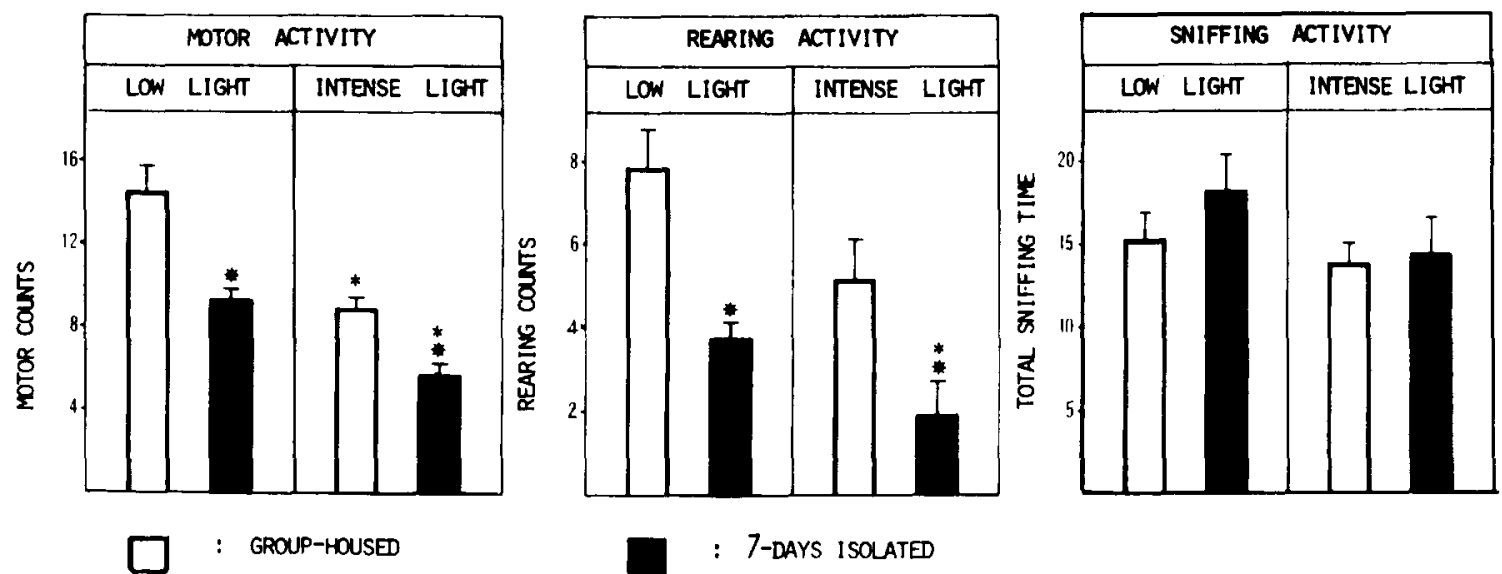

Fig. 1. Effect of housing conditions before and light conditions during testing on motor, rearing and sniffing activities of rats. Grouphoused or 7-days isolated rats were tested under intense or low light conditions. Data represent mean scores for motor and rearing activities and mean duration of sniffing behavior per group of rats $(n=8$ /group) during a 3-min observation period in a small open field. The vertical bars indicate S.E.M. Results of two-way ANOVA are as follows. Motor activity: $F$ (housing) $25.57(1.28) P<0.001$; $F$ (light) $30.28(1.28) P<0.001 ; F$ (housing $\times$ light) 1.42 (1.28) n.s. Rearing activity: $F$ (housing) 22.07 (1.28) $P<0.001 ; F$ (light) 7.94 (1.28) $P<0.01 ; F$ (housing $\times$ light) 0.22 (1.28) n.s. Sniffing activity: $F$ (housing) 1.01 (1.28) n.s.; $F$ (light) $2.12(1.28)$ n.s.; $F$ (housing $\times$ light) $0.24(1.28)$ n.s. * Different from group-housed animals tested under identical light conditions $(P<0.05$; Student's $t$-test $) ;{ }^{*}$ different from identically housed animals tested under low light conditions $(P<0.05$, Student's $t$-test $)$.

tensity and increased the motor activity of singlehoused rats tested under high light intensity (Fig. 2). The $\mathrm{ED}_{50}$ of the peptide was approximately 0.03 $\mu \mathrm{g} / \mathrm{kg}$ and $0.015 \mu \mathrm{g} / \mathrm{kg}$ respectively. The motor activity of group-housed rats tested under intense light and that of single-housed rats tested under low light intensity was not affected by treatment with ORG 2766. Therefore, in the following experiments only the effect of peptides on motor activity of group- housed rats tested under low light intensity and single-housed rats tested under high light intensity was assessed. $\mathrm{ACTH}_{4-10}$ did not influence the motor activity of single-housed rats tested under intense light, but the highest dose $(100 \mu \mathrm{g} / \mathrm{kg})$ of the peptide tested significantly increased the already high level of motor activity of the group-housed rats tested under low light intensity (Fig. 3).

In order to elucidate the essential structure for the

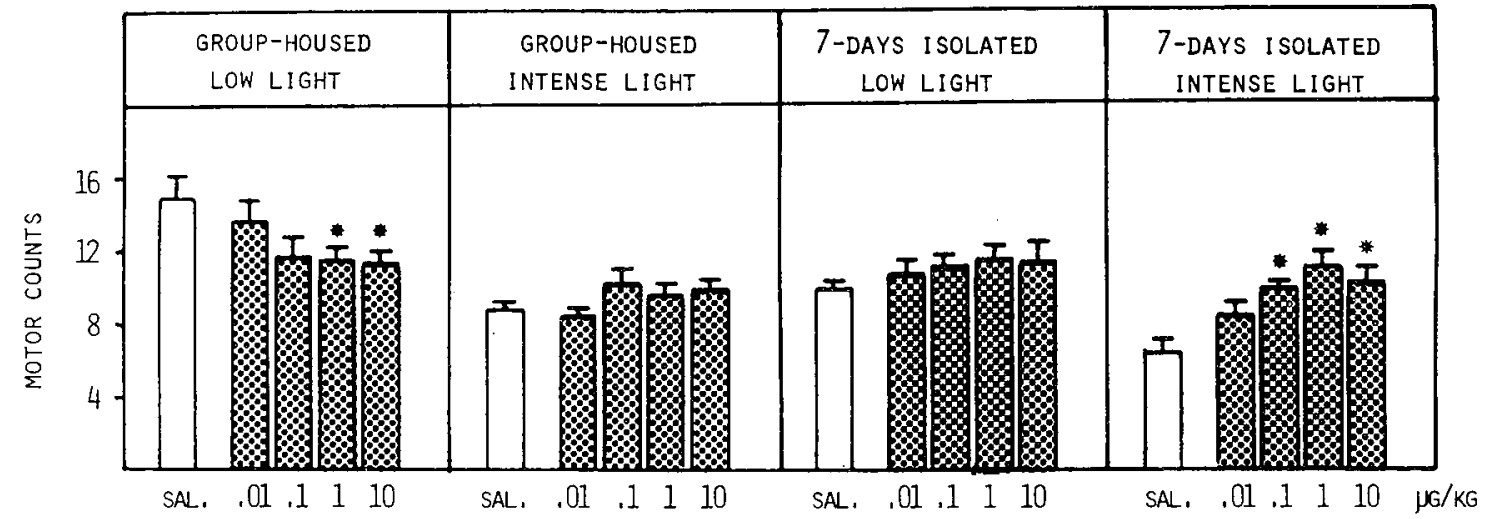

Fig. 2. Influence of ORG 2766 treatment on changes in motor activity induced by housing and test conditions. Rats were group housed or 7-days isolated and tested under low or intense light in a small open field. Groups of animals $(n=8 /$ group $)$ were s.c. injected with saline or graded doses $(0.01-10 \mu \mathrm{g} / \mathrm{kg})$ of ORG $276650 \mathrm{~min}$ before testing. Mean scores for motor activity per group of rats are depicted. Vertical bars indicate S.E.M. Results of 3-way ANOVA are as follows. $F$ (housing) $8.89(1.140) P<0.003 ; F$ (light) 57.52 (1.140) $P<0.001$; $F$ (treatment) 1.05 (4.140) n.s. $F$ (housing $\times$ light) $5.65(1.140) P<0.001$; $F$ (housing $\times$ treatment) $5.58(4.140) P<$ $0.001 ; F$ (light $\times$ treatment) 5.65 (4.140) $P<0.02 ; F$ (housing $\times$ light $\times$ treatment) $0.55(4.140)$ n.s. * Different from saline-treated animals, tested and housed under identical conditions $(P<0.05$, Newman-Keuls). 


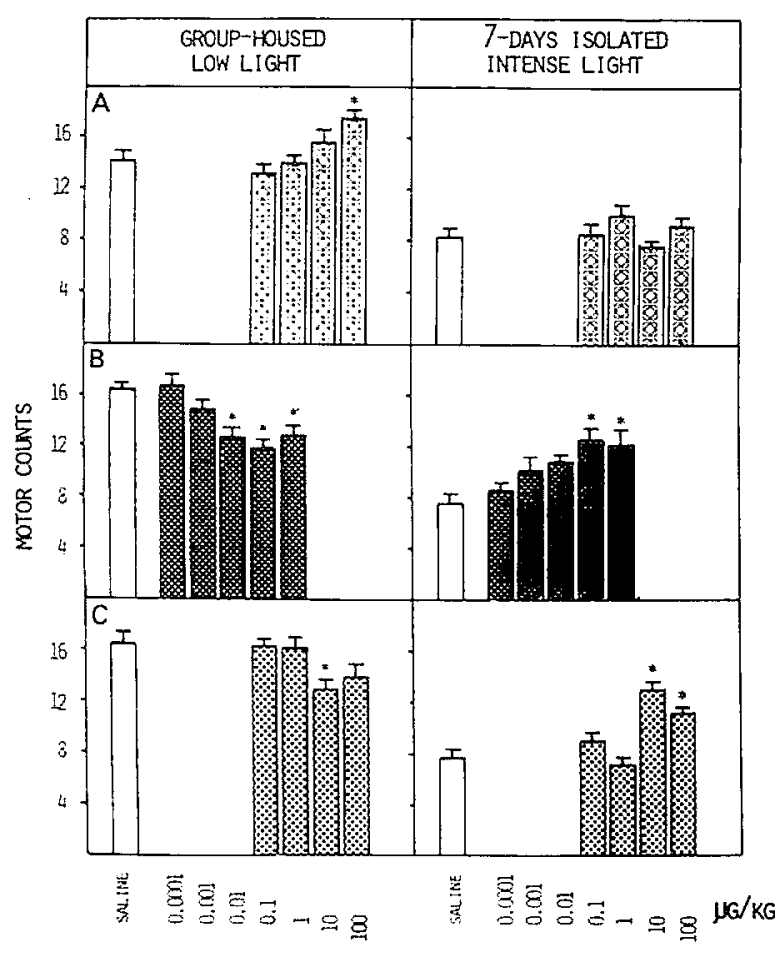

Fig. 3. Influence of treatment with $\mathrm{ACTH}_{4-10}$ (A), WB1438 (B) or PDLP (C) on changes in motor activity induced by housing and test conditions. Group-housed rats were tested under low light conditions and 7-days isolated rats were tested under intense light conditions. Saline or graded doses $(0.1 \mathrm{ng}-100$ $\mu \mathrm{g} / \mathrm{kg}$ ) of the peptides were injected s.c. $50 \mathrm{~min}$ before testing. Data represent mean scores for motor activity per group of rats ( $n=5-10$ /group). Vertical bars represent S.E.M. Results of 2way ANOVA are as follows. $\mathrm{ACTH}_{4-10}: F$ (housing/light) 178.64 (1.70) $P<0.001 ; F$ (treatment) 3.54 (4.70) $P<0.01$; $F$ (housing/light $\times$ treatment) $3.48(4.70) P<0.01$. WB1438: $F$ (housing/light) 68.58 (1.53) $P<0.001 ; F$ (treatment) 1.10 (5.53) n.s.; $F$ (housing/light $\times$ treatment) $4.07(5.53) P<0.003$. PDLP: $F$ (housing/light) 178.99 (1.65) $P<0.001 ; F$ (treatment) 1.38 (4.65) n.s.; $F$ (housing/light $\times$ treatment) 19.91 (4.65) $P<$ 0.003 . ${ }^{*}$ Different from saline-treated animals tested and housed under identical conditions ( $P<0.05$, Newman-Keuls).

described effect of ORG 2766 a number of peptides related to ORG 2766 and $\mathrm{ACTH}_{4-10}$ were tested. The peptides PDLP and WB1438 mimicked the effect of ORG 2766 in both group- and single-housed rats tested under low and intense light conditions respectively (Fig. 3). PDLP was about 100-200 times less potent than ORG $2766\left(\mathrm{ED}_{50}: 4\right.$ and $3 \mu \mathrm{g} / \mathrm{kg}$ for the two test conditions), while the peptide WB1438 was approximately $10-30$ times more potent than ORG $2766\left(\mathrm{ED}_{50}: 0.002\right.$ and $0.0006 \mu \mathrm{g} / \mathrm{kg}$ for the two test conditions). The peptides $\mathrm{ACTH}_{4-7}$ and [Met/ $\mathrm{O}_{2} / \mathrm{ACTH}_{4-7}$ administered in a dose of $100 \mu \mathrm{g} / \mathrm{kg}$ did not affect the motor activity of rats under the two experimental conditions, while $\mathrm{ACTH}_{7-111}$. [D$\mathrm{Phe}^{7} \mathrm{ACTH}_{4-10}$ and $\gamma$-MSH injected in a dose of 100 $\mu \mathrm{g} / \mathrm{kg}$ tended to mimic the effect of $\mathrm{ACTH}_{4-10}$ on the motor activity of rats (data not shown). These peptides increased, but not significantly, the motor activity of the group-housed animals tested under low light conditions and did not affect the motor activity of the isolated animals tested under intense light.

Next, the influence of the opiate antagonist naltrexone on the effect of ORG 2766 was explored. A subcutaneous injection with naltrexone $(450 \mu \mathrm{g} / \mathrm{kg})$ $100 \mathrm{~min}$ before testing did not affect the motor activity of group- and single-housed rats tested under low and intense light respectively (Fig. 4). However, an identical injection of naltrexone completely reversed the effect of ORG 2766 on motor activity of rats.

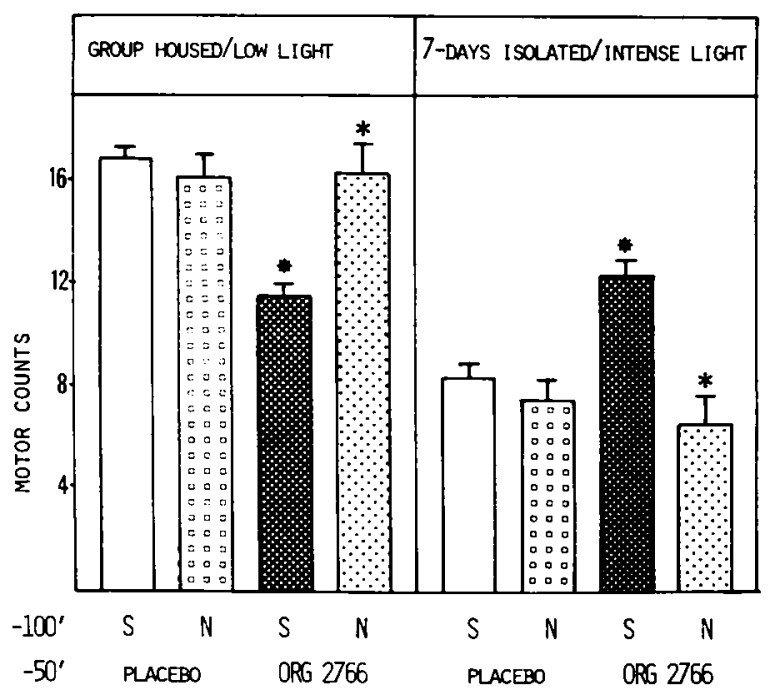

Fig. 4. Influence of housing and test conditions on motor activity of rats; interaction between naltrexone and ORG 2766 treatment. Group-housed rats were tested under low light conditions and 7-days isolated rats were tested under intense light conditions. Saline (S) or naltrexone (N, $450 \mu \mathrm{g} / \mathrm{kg}$ ) was injected s.c. $100 \mathrm{~min}$ before testing (pretreatment), saline (placebo) or ORG $2766(1 \mu \mathrm{g} / \mathrm{kg})$ was injected s.c. $50 \mathrm{~min}$ before testing (treatment). Data are expressed as mean scores for motor activity \pm S.E.M. (vertical bars) per group of rats $(n=8 /$ group). Results of 3-way ANOVA: $F$ (housing/light) 154.51 (1.56) $P<$ 0.001 ; $F$ (pretreatment) 1.16 (1.56) n.s.; $F$ (treatment) 0.91 (1.56) n.s.; $F$ (housing/light $\times$ pretreatment) 27.67 (1.56) $P<$ $0.001 ; F$ (housing/light $\times$ treatment) $13.73(1.56) P<0.001$; $F$ (pretreatment $\times$ treatment) $0.23(1.56)$ n.s.; $F$ (housing/light $\times$ pretreatment $\times$ treatment) $26.41(1.56) P<0.001 .{ }^{*}$ Different from saline pretreatment $(P<0.05$, Newman-Keuls); * different from placebo treatment $(P<0.05$, NewmanKeuls). 


\section{DISCUSSION}

Motor activity of rats was decreased by a 7-day isolation period before or by intense light during testing in a small open field. The effect of 7 days isolation before testing was additive to the effect of intense light during testing. These environmental factors are also capable of modulating social behavior of rats in dyadic encounters ${ }^{20,21}$. However, whereas the high level of illumination decreases both social and motor activity, the isolation procedure increases and decreases social and motor activity respectively. The effects of ORG 2766 and $\mathrm{ACTH}_{4-10}$ on motor activity resemble to a certain extent those on social behavior, i.e. ORG 2766 attenuates the effect of environmental changes on both behaviors and may thus have a 'normalizing' effect, while $\mathrm{ACTH}_{4-10}$ tends to potentiate some influences of the environmental changes on these behaviors.

The experimental procedure, i.e. placing a rat in a novel environment under high or low level of illumination will certainly result in an activation of the pituitary-adrenal axis. Indeed, exposure of rats to a novel environment has been shown to stimulate the secretion of corticosterone (CS) from the adrenal cortex ${ }^{12}$. The effects of housing and test conditions on motor activity, however, are already present within 3 min of testing, whereas no significant release of CS in response to a stressful stimulus occurs within this period ${ }^{2}$. Also, the observation that CS increases social interactions ${ }^{11}$, while the experimental procedure used in the present study, i.e. testing rats under intense light in an unfamiliar environment, decreases time spent in social interactions, does not favour a role of CS in this respect. Moreover, ORG 2766 and $\mathrm{ACTH}_{4-10}$ which, as shown in the present study, modulate the changes in motor activity induced by the alterations in the environment before or during testing, have negligible effects on the adrenal cortex ${ }^{3,18}$. Thus, it is likely that $\mathrm{ACTH}_{4-10}$ and ORG 2766 produce these effects by a direct action on the brain.

The results from the structure activity relationship study suggest that the active part of ORG 2766 in inducing the present effects is located in the $\mathrm{COOH}$ terminal sequence Phe-D-Lys-Phe (PDLP). Peptides containing this structure, i.e. ORG 2766, WB1438 and PDLP, exerted the 'normalizing' effect on the environmentally induced changes in motor activity. That relatively high doses of PDLP were needed could be due to a poor penetration of this substance into the brain or to rapid degradation. The increasing effect of $\mathrm{ACTH}_{4-10}$ on motor activity in grouphoused rats under intense light conditions may also reside in the $\mathrm{COOH}$-terminal part of the molecule. Peptides containing this or a closely related structure, e.g. ACTH $_{7-10}$, [D-Phe ${ }^{7} \mathrm{ACTH}_{4-10}$ and $\gamma$ $\mathrm{MSH}$, mimicked the effect of $\mathrm{ACTH}_{4-10}$, while the $\mathrm{NH}_{2}$-terminal parts of $\mathrm{ACTH}_{4-10}$ and ORG 2766, i.e. $\mathrm{ACTH}_{4-7}$ and $\left[\mathrm{Met} / \mathrm{O}_{2} / \mathrm{ACTH}_{4-7}\right.$, did not affect the environmentally induced changes in motor activity. Substitution of the L-phenylalanine at the 7th amino acid position of $\mathrm{ACTH}_{4-10}$ by its D-isomer did not alter the effect of the peptide on motor activity. These two peptides have opposite effects on active avoidance behavior ${ }^{4,6,14,30}$, while there is no difference in their action on passive avoidance behavior ${ }^{6,7}$ and on habituation to and exploration of novel environment $^{10}$.

Pretreatment of rats with the opiate antagonist naltrexone completely blocked the 'normalizing' effect of ORG 2766 on environmentally induced changes in motor activity. Naltrexone also antagonizes the 'normalizing' effect of ORG 2766 on social behavior of rats ${ }^{20}$. These observations suggest an involvement of opioid systems in the effect of ORG 2766 and probably of PDLP. This is consistent with the finding of Fekete and De Wied ${ }^{8}$, showing that the naltrexone-sensitive effect of ORG 2766 resides in the tripeptide PDLP. Interestingly, $\mathrm{ACTH}_{4-10}$ and its $\mathrm{COOH}$-terminal fragments seem to enhance the environmentally induced changes in motor activity. In this respect these peptides have an effect opposite to ORG 2766 and may thus act as opiate antagonists. Indeed, other studies have shown that under certain conditions peptides derived from ACTH have opiate antagonist-like properties. The enhancing effect of opioid antagonists on stress-induced sedation is mimicked by $\mathrm{ACTH}_{4-10}$ and $\mathrm{ACTH}_{7-10}$ (refs. 15, 29). These two peptides are able to displace ${ }^{125}$ I-labelled morphine from morphine antiserum and to mimic the morphine-induced inhibition of contraction of mouse vas deference ${ }^{23}$. Moreover, it has been shown that $\mathrm{ACTH}_{4-10}$ and the structurally related $\gamma$-MSH have affinity for brain opiate binding sites ${ }^{16.25-27}$ and that they counteract the morphine- or $\beta$-endorphin-in- 
duced analgesia in rats ${ }^{16.26 .27}$. These observations led us to hypothesize that under certain conditions $\mathrm{ACTH}_{4-10}$ and $\mathrm{ACTH}_{7-10}$ may act as functional antagonists of endogenous opioid systems, while ORG 2766 and its $\mathrm{COOH}$-terminal fragment, PDLP, may serve as opioid agonists or may elicit release of endogenous opioid peptides.

ORG 2766 'normalizes' the environmentally induced changes in motor activity as well as social activity. Thus, this peptide may affect the integration of

\section{REFERENCES}

1 Braverman, A., Hamdy, R., Hendrickson, E., Meisner, P., Perrera, J. and Pigache, R.M., Report to Organon, 1980.

2 De Souza, E.B. and Van Loon, G.R., Stress-induced inhibition of the plasma corticosterone response to a subsequent stress in rats: a non-adrenocorticotropin-mediated mechanism, Endocrinology, 110 (1982) 23-33.

3 De Wied, D., Effects of peptide hormones on behaviour. In W.F. Ganong and L. Martini (Eds.), Frontiers in Neuroendocrinology, Oxford University Press, New York, 1969, pp. 97-140.

4 De Wied, D., Witter, A. and Greven, H.M., Behaviorally active ACTH analogues, Biochem. Pharmacol, 24 (1975) $1463-1468$.

5 De Wied, D. and Jolles, J., Neuropeptides derived from pro-opiocortin: behavioral, physiological and neurochemical effects, Physiol. Rev., 62 (1982).

6 Fekete, M. and De Wied, D., Potency and duration of action of the $\mathrm{ACTH}_{4-9}$ analog (ORG 2766) as compared to $\mathrm{ACTH}_{4-10}$ and (D-Phe7) $\mathrm{ACTH}_{4-10}$ on active and passive avoidance behavior of rats, Pharmacol. Biochem. Behav., 16 (1982) 387-392.

7 Fekete, M. and De Wied, D., Dose-related facilitation and inhibition of passive avoidance behavior by the $\mathrm{ACTH}_{4-9}$ analog (ORG 2766), Pharmacol. Biochem. Behav., 17 (1982) $177-182$.

8 Fekete, M. and De Wied, D., Naltrexone-insensitive facilitation and naltrexone-sensitive inhibition of passive avoidance behavior of the $\mathrm{ACTH}_{4-9}$ analog (ORG 2766) are located in two different parts of the molecule, Eur. J. Pharmacol., 81 (1982) 441-448.

9 Ferris, S.H., Reisberg, B. and Gershon, S., Neuropeptide effects on cognition in the elderly. In W. Poon (Ed.), Aging in the 1980s: Selected Contemporary Issues in the Psychology of Aging, American Psychological Association, Washington, 1980.

10 File, S.E., ACTH, but not corticosterone impairs habituation and reduces exploration, Pharmacol. Biochem. Behav., 9 (1978) 161-166.

11 File, S.E. and Velluci, S.V., Studies on the role of ACTH and of 5-HT in anxiety, using an animal model, J. Pharm. Pharmacol., 30 (1978) 105-110.

12 File, S.E. and Peet, L.A., The sensitivity of the rat corticosterone response to environmental manipulation and to chronic chlordiazepoxide treatment, Physiol. Behav., 25 (1980) 753-758.

13 File, S.E., Contrasting effects of ORG 2766 and $\gamma$-MSH on sensory stimuli rather than the specific motor output systems of these behaviors. Accordingly, preliminary studies suggest that the amygdala, which has been implicated in several processes which relate environmental stimuli to behavioral, visceral and endocrine responses ${ }^{17,19}$, may be the target structure for this action of ORG 2766. The 'normalizing' effect of ORG 2766 on 'disturbances' in behavior induced by changes in the environment may be relevant for possible therapeutic applications of this peptide.

serial and exploratory behavior in the rat, Peptides, 2 (1981) 255-260.

14 Flood, J.F., Jarvik, M.E., Bennett, E.L. and Orme, A.E., Effects of ACTH peptide fragments on memory formation, the neuropeptides, Pharmacol. Biochem. Behav., 5, Suppl. 1 (1976) 41-51.

15 Galina, Z.H., Amit, Z. and Van Ree, J.M., Behavioral support for an ACTH receptor in the CNS, Peptides, 6 (1985) 285-291.

16 Gispen, W.H., Buitelaar, J., Wiegant, V.M., Terenius, L. and De Wied, D., Interaction between ACTH fragments brain opiate receptors and morphine-induced analgesia, Eur. J. Pharmacol., 39 (1976) 393-397.

17 Gloor, P., Inputs and outputs of the amygdala: what the amygdala is trying to tell the rest of the brain. In K.E. Livingston and O. Hornykiewicz (Eds.), Limbic Mechanisms, Plenum, New York, 1978, pp. 189-209.

18 Greven, H.M. and De Wied, D., The influence of peptides derived from corticotropin (ACTH) on performance. Structure-activity studies, Prog. Brain Res., 39 (1973) $429-442$.

19 Kaada, B.R., Stimulation and regional ablation of the amygdaloid complex with reference to functional representations. In B.E. Eleftheriou (Ed.), The Neurobiology of the Amygdala, Plenum, New York, 1972, pp. 205-281.

20 Niesink, R.J.M. and Van Ree, J.M., Normalizing effect of the $\mathrm{ACTH}_{4-9}$ analog ORG 2766 on 'disturbed' social behavior of rats; implication of endogenous opioid systems, Science, 221 (1983) 960-962.

21 Niesink, R.J.M. and Van Ree, J.M., Analysis of the facilitatory effect of the $\mathrm{ACTH}_{4-9}$ analog ORG 2766 on active social contact in rats, Life Sci., 34 (1984) 961-970.

22 Pigache, R.M. and Rigter, H., Effects of peptides related to ACTH on mood and vigilance in man, Front. Horm. Res., 8 (1981) 193-207.

23 Plomp, G.J.J. and Van Ree, J.M., Adrenocorticotrophic hormone fragments mimic the effect of morphine in vitro, Br. J. Pharmacol., 64 (1978) 223-227.

24 Sandman, C.A., Walker, B.B. and Lawton, C.A., An ana$\log$ of $\mathrm{MSH} / \mathrm{ACTH}_{4-9}$ enhances interpersonal and environmental awareness in mentally retarded adults, Peptides, 1 (1980) 109-114.

25 Terenius, L., Gispen, W.H. and De Wied, D., ACTH-like peptides and opiate receptors in the rat brain: structure-activity studies, Eur. J. Pharmacol., 33 (1975) 395-399.

26 Van Ree, J.M., Bohus, B., Csontos, K.M., Gispen, W.H., Greven, H.M., Nijkamp, F.P., Opmeer, F.A., De Rotte, A.A., Van Wimersma Greidanus, Tj.B., Witter, A. and 
De Wied, D., $\gamma$-Melanotropin and brain function. In D. Evered and G. Lawrenson (Eds.), Peptides of the Pars Intermedia, Pitman Medical, London, 1981, pp. 263-276.

27 Van Ree, J.M., Bohus, B., Csontos, K.M., Gispen, W.H., Greven, H.M., Nijkamp, F.P., Opmeer, F.A., De Rotte, A.A., Van Wimersma Greidanus, Tj.B., Witter, A. and De Wied, D., Behavioral profile of $\gamma$-MSH: relationship with ACTH and $\beta$-endorphin action, Life Sci., 28 (1981) 2875-2888.

28 Van Ree, J.M. and Wolterink, G., Injection of low doses of apomorphine into the nucleus accumbens of rats reduces locomotor activity, Eur. J. Pharmacol., 72 (1981) 107-111.
29 Van Ree, J.M., Wolterink, G., Galina, Z.H. and Niesink, R.J.M., Interaction between environment and behavior: effects of ACTH-neuropeptides. In D. De Wied and W. Ferrari (Eds.), Central Actions of ACTH and Related Peptides, Symposia in neuroscience IV, Liviana Press, Padova, 1986, pp. 139-146.

30 Van Wimersma Greidanus, Tj.B. and De Wied, D., Effects of systemic and intracerebral administration of two opposite acting ACTH-related peptides on extinction of conditioned avoidance behavior, Neuroendocrinology, 7 (1971) 291-301. 